\title{
Skeletal mineralogy of coral recruits under high temperature and $p \mathrm{CO}_{2}$
}

\author{
T. Foster ${ }^{1,2,3}$ and P. L. Clode ${ }^{2,4}$ \\ ${ }^{1}$ UWA School of Earth and Environment, University of Western Australia, Crawley, Western Australia, 6009, Australia \\ ${ }^{2}$ UWA Oceans Institute, University of Western Australia, Crawley, Western Australia, 6009, Australia \\ ${ }^{3}$ ARC Centre of Excellence for Coral Reef Studies, University of Western Australia, Crawley, \\ Western Australia 6009, Australia \\ ${ }^{4}$ Centre for Microscopy, Characterisation and Analysis, University of Western Australia, Crawley, \\ Western Australia, 6009, Australia
}

Correspondence to: T. Foster (taryn.foster@research.uwa.edu.au)

Received: 30 June 2015 - Published in Biogeosciences Discuss.: 7 August 2015

Revised: 15 December 2015 - Accepted: 29 December 2015 - Published: 18 March 2016

\begin{abstract}
Aragonite, which is the polymorph of $\mathrm{CaCO}_{3}$ precipitated by modern corals during skeletal formation, has a higher solubility than the more stable polymorph calcite. This higher solubility may leave animals that produce aragonitic skeletons more vulnerable to anthropogenic ocean acidification. It is therefore important to determine whether scleractinian corals have the plasticity to adapt and produce calcite in their skeletons in response to changing environmental conditions. Both high $p \mathrm{CO}_{2}$ and lower $\mathrm{Mg} / \mathrm{Ca}$ ratios in seawater are thought to have driven changes in the skeletal mineralogy of major marine calcifiers in the past $\sim 540 \mathrm{Ma}$. Experimentally reduced $\mathrm{Mg} / \mathrm{Ca}$ ratios in ambient seawater have been shown to induce some calcite precipitation in both adult and newly settled modern corals; however, the impact of high $p \mathrm{CO}_{2}$ on the mineralogy of recruits is unknown. Here we determined the skeletal mineralogy of 1-month-old Acropora spicifera coral recruits grown under high temperature $\left(+3{ }^{\circ} \mathrm{C}\right)$ and $p \mathrm{CO}_{2}(\sim 900 \mu \mathrm{atm})$ conditions, using X-ray diffraction and Raman spectroscopy. We found that newly settled coral recruits produced entirely aragonitic skeletons regardless of the treatment. Our results show that elevated $p \mathrm{CO}_{2}$ alone is unlikely to drive changes in the skeletal mineralogy of young corals. Not having an ability to switch from aragonite to calcite precipitation may leave corals and ultimately coral reef ecosystems more susceptible to predicted ocean acidification. An important area for prospective research would be the investigation of the combined impact
\end{abstract}

of high $p \mathrm{CO}_{2}$ and reduced $\mathrm{Mg} / \mathrm{Ca}$ ratio on coral skeletal mineralogy.

\section{Introduction}

Scleractinian corals are the major reef builders, with their skeletons providing the structural basis for the habitats of many marine organisms. In modern adult corals, the skeletons are comprised of aragonite, a polymorph of calcium carbonate $\left(\mathrm{CaCO}_{3}\right)$ whose stability is highly sensitive to changes in ocean $p \mathrm{CO}_{2}$ (Orr et al., 2005; Feely et al., 2009). However, examination of a 70 million year old scleractinian coral fossil showed that some ancient corals were able to produce skeletons entirely of calcite (Stolarski et al., 2007), the most stable and least soluble polymorph of $\mathrm{CaCO}_{3}$ (de Leeuw et al., 1998; Boulos et al., 2014). Throughout the Phanerozoic (past $540 \mathrm{Ma}$ ), there have been oscillations between calcite and aragonite as the dominant polymorph precipitated by major reef building organisms. During this time period there have been three aragonite-facilitating periods or "aragonite seas" and two calcite-facilitating periods or "calcite seas". The cause of these transitions in mineralogy has been the topic of much debate over the past 30 years. One of the most important factors affecting skeletal mineralogy is the magnesium to calcium ratio $(\mathrm{Mg} / \mathrm{Ca})$ of seawater (Sandberg, 1983; Ries, 2010). If the $\mathrm{Mg} / \mathrm{Ca}>2$, then aragonite is predominantly precipitated and if the $\mathrm{Mg} / \mathrm{Ca}<2$, 
then calcite is predominantly precipitated. Currently, conditions favour aragonite precipitation, with modern seawater having a $\mathrm{Mg} / \mathrm{Ca}$ ratio of 5.2 (Lowenstein et al., 2001). A recent study found $\mathrm{CaCO}_{3}$ polymorph precipitation to be a function of both $\mathrm{Mg} / \mathrm{Ca}$ ratio and temperature, with aragonite precipitated at high temperature and $\mathrm{Mg} / \mathrm{Ca}$ ratio and calcite precipitated at low temperature and $\mathrm{Mg} / \mathrm{Ca}$ ratio (Balthasar and Cusack, 2015). Changes in atmospheric $p \mathrm{CO}_{2}$ are also thought to contribute to changes in skeletal mineralogy (Sandberg, 1983; Zhuravlev and Wood, 2009; Lee and Morse, 2010), with rising $p \mathrm{CO}_{2}$ and subsequent reductions in carbonate saturation state, potentially favouring the precipitation of minerals with higher stability and lower Mg content, such as calcite (Morse et al., 2006; Zhuravlev and Wood, 2009). The polymorphism of abiotically precipitated calcium carbonate varies with both temperature and $p \mathrm{CO}_{2}$, but occurs only at low $\mathrm{Mg} / \mathrm{Ca}$ ratios (Lee and Morse, 2010; Balthasar and Cusack, 2015). However less is known about the polymorphism of biologically precipitated $\mathrm{CaCO}_{3}$. If ocean acidification favours the deposition of more stable carbonate minerals such as calcite (Mackenzie et al., 1983; Morse et al., 2006; Andersson et al., 2008), then organisms producing less stable aragonite skeletons will likely be more vulnerable to changes in ocean chemistry under high $p \mathrm{CO}_{2}$. Alternatively, organisms will be much less vulnerable if, under high $p \mathrm{CO}_{2}$ conditions, they have the ability to switch from predominantly aragonite to calcite precipitation, especially in their early developmental stages.

It is therefore important to determine whether modern aragonitic corals, like some of their ancestors, are able to produce calcite in response to changing seawater chemistry. Initial work on coral skeletal mineralogy reported the presence of calcite in modern corals (Houck et al., 1975; Constantz and Meike, 1990); however, contamination by diagenetic recrystallization (Nothdurft and Webb, 2009) and deposits from microboring organisms (Nothdurft et al., 2007) and coralline algae (Goffredo et al., 2012) were later proposed to be the source of the calcite, rather than primary calcitic formation by the coral. Adult corals grown under low $\mathrm{Mg} / \mathrm{Ca}$ ratios simulating "calcite seas", have been shown to produce significant amounts of calcite (Reis et al., 2006); however again, some of this calcite production may be due to secondary infilling of pore spaces (Reis et al., 2006; Ries, 2010). Nevertheless it is accepted that modern adult corals grown under current ambient conditions have entirely aragonitic skeletons (Cuif et al., 1999).

Much less is known about the mineralogy of corals in the early post-recruitment phases. Early work on the mineralogy of new recruits reported the presence of calcite in only the very early post-settlement stages (Wainwright, 1963; Vandermeulen and Watabe, 1973), leading to the assumption that unlike adults, newly settled recruits were able to precipitate both calcite and aragonite under ambient conditions (Goffredo et al., 2012). However, new recruits of Acropora millepora grown under carefully controlled ambient conditions did not show any evidence of calcite in their skeleton (Clode et al., 2011) with these authors concluding that initial reports of calcite in recruits was also likely to be artefactual. Similarly, an experiment growing new recruits under a range of seawater $\mathrm{Mg} / \mathrm{Ca}$ ratios, reported that even under the lowest $\mathrm{Mg} / \mathrm{Ca}$ ratio (0.5), the skeletal mineralogy was still dominated by aragonite and under current ambient conditions $(\mathrm{Mg} / \mathrm{Ca}$ ratio $=5.3)$ skeletons were composed entirely of aragonite (Higuchi et al., 2014). Interestingly however, this study confirmed that coral recruits are capable of producing some primary calcite in their skeletons if the water chemistry is adjusted to "calcite sea" conditions (low $\mathrm{Mg} / \mathrm{Ca}$ ).

The impact of elevated $p \mathrm{CO}_{2}$ on the skeletal mineralogy of new recruits is yet to be investigated. Here we tested whether the treatment conditions of high temperature, high $p \mathrm{CO}_{2}$, or a combination of high temperature and high $p \mathrm{CO}_{2}$, affected the skeletal mineralogy of newly settled corals. Specifically, we question whether high $p \mathrm{CO}_{2}$ and reduced carbonate saturation facilitate the production of calcite within coral recruit skeletons.

\section{Methods}

\subsection{Treatment conditions}

A detailed description of the coral culturing methods and experimental set-up is given in Foster et al. (2015). Briefly, adult Acropora spicifera colonies were collected from the Houtman Abrolhos Islands in Western Australia prior to spawning and maintained under ambient conditions $\left(\sim 24^{\circ} \mathrm{C}\right.$ and $\mathrm{pH}$ 8.1). Larvae were similarly cultured and maintained under ambient conditions until they were motile, at which point they were transferred to treatment tanks. Treatment conditions were the following: ambient temperature and $p \mathrm{CO}_{2}$ (Control: $24^{\circ} \mathrm{C}, \sim 250 \mu \mathrm{atm}$ ), high temperature and ambient $p \mathrm{CO}_{2}$ (high temperature: $27^{\circ} \mathrm{C}, \sim 250 \mu \mathrm{atm}$ ), ambient temperature and high $p \mathrm{CO}_{2}$ (high $p \mathrm{CO}_{2}: 24^{\circ} \mathrm{C}, \sim$ $900 \mu \mathrm{atm}$ ), and high temperature plus high $p \mathrm{CO}_{2}$ (high temperature $\left.+p \mathrm{CO}_{2}: 27^{\circ} \mathrm{C}, \sim 900 \mu \mathrm{atm}\right)$. See Table 1 for more detail on the experimental conditions.

\subsection{Processing of skeletons}

Once the coral larvae had settled, the recruits were grown for 4 weeks under treatment conditions, before the experiment was concluded. To remove organic material, polyps were immersed in 3-7\% sodium hypochlorite $(\mathrm{NaOCl})$ and rinsed three times in de-ionized water. The skeletons were then stored in $100 \%$ ethanol until further examination and analysis were possible.

\subsection{X-ray diffraction analysis}

Bulk analysis of the skeletal mineralogy was conducted by obtaining X-ray diffraction (XRD) patterns of the skele- 
Table 1. Physical and chemical conditions maintained for the duration of the experiment (mean \pm SD). Table from Foster et al. (2015).

\begin{tabular}{lccccc}
\hline Treatment & Temperature $\left({ }^{\circ} \mathrm{C}\right)$ & $\mathrm{pH}_{\mathrm{T}}$ & $\mathrm{TA}\left(\mu \mathrm{mol} \mathrm{kg}{ }^{-1}\right)$ & $p \mathrm{CO}_{2}(\mu \mathrm{atm})$ & $\Omega_{\mathrm{ar}}$ \\
\hline Control & $24.4 \pm 0.5$ & $8.22 \pm 0.05$ & $2308 \pm 40$ & $242 \pm 22$ & $4.51 \pm 0.14$ \\
High temperature & $27.6 \pm 0.8$ & $8.18 \pm 0.05$ & $2312 \pm 26$ & $275 \pm 24$ & $4.68 \pm 0.17$ \\
High $p \mathrm{CO}_{2}$ & $24.1 \pm 0.6$ & $7.77 \pm 0.06$ & $2307 \pm 30$ & $872 \pm 58$ & $1.93 \pm 0.08$ \\
High temperature $+p \mathrm{CO}_{2}$ & $27.4 \pm 0.9$ & $7.75 \pm 0.08$ & $2309 \pm 32$ & $976 \pm 103$ & $2.03 \pm 0.12$ \\
\hline
\end{tabular}

TA: total alkalinity; $p \mathrm{CO}_{2}$ : partial pressure of carbon dioxide; $\Omega_{\mathrm{ar}}$ : aragonite saturation state.

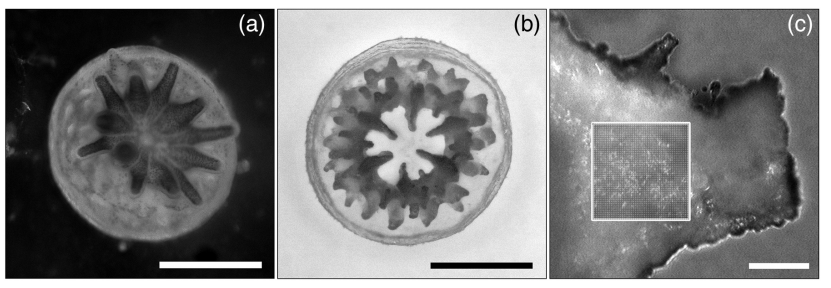

Figure 1. One-month-old living Acropora spicifera recruit (a), a typical Acropora spicifera recruit skeleton with organic material removed (b) and crushed skeletal material showing a typical $\sim 60 \mu \mathrm{m}^{2}$ scan area grid analyzed by Raman spectroscopy (c). Scale bars for (a) and (b) $=500 \mu \mathrm{m}$ and scale bar for $(\mathbf{c})=40 \mu \mathrm{m}$.

tal material. Subsets of five juvenile skeletons were randomly selected from each treatment. Skeletons were removed from the ethanol and air dried, then detached from the transparency paper using a scalpel and gently crushed. The crushed skeletal material from each treatment was mounted on a low background holder (off-angle piece of single crystal silicon) and attached to a reflection spinner stage. A PANalytical Empyrean X-ray diffractometer was used with $\mathrm{CuK}_{\alpha}$ radiation to record the XRD patterns. The scanning rate was $250 \mathrm{~s}$ per step in $2 \theta$ ranging from 10 to $80^{\circ}$, with a step size of $0.006^{\circ}$. XRD patterns of skeletal material were compared to the XRD peaks for ICSD (Inorganic Crystal Structure Database) aragonite and calcite standards .

\subsection{Raman spectroscopy}

XRD provides an average analysis for the entire sample; however for calcium carbonate samples, Raman spectroscopy has been shown to have lower detection limits and lower rates of error, though only the surfaces of selected fragments can be analyzed at any one time (Kontoyannis and Vagenas, 2000). Therefore, complementary Raman spectroscopy was also used to check the skeletons for the presence of calcite within discreet skeletal fragments. A further five skeletons from each treatment were randomly selected and each skeleton was individually analyzed. Raman spectra were collected from 10 random areas $(\sim 60 \times 60 \mu \mathrm{m})$ in the crushed skeletal material of each sample, using a $633 \mathrm{~nm}$ red Helium neon laser. Spectra were measured every $1 \mu \mathrm{m}$ along the gridded $\sim 60 \mu \mathrm{m}^{2}$ area (Fig. 1) for each of the 10 areas

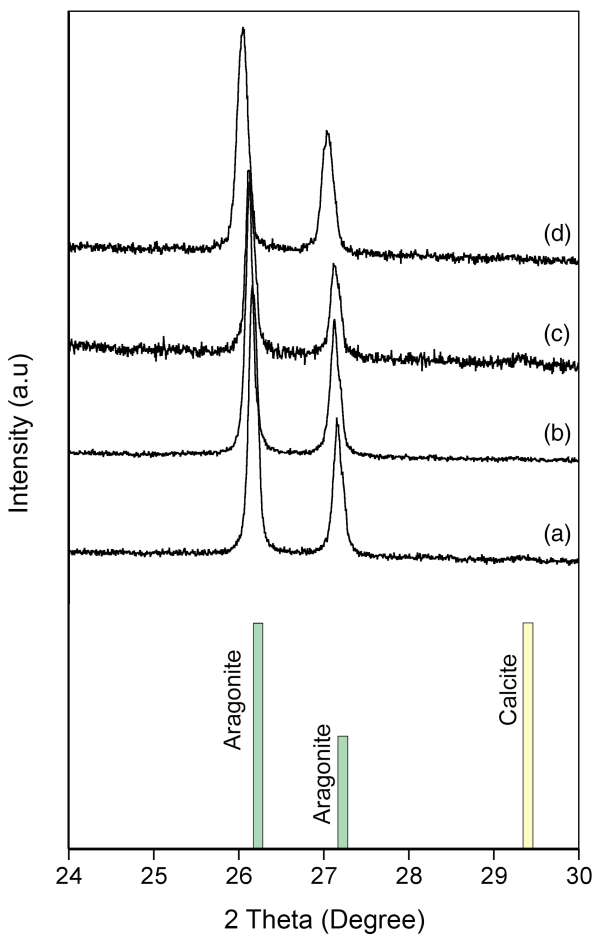

Figure 2. XRD patterns for Acropora spicifera coral recruit skeletons grown under control (a), high temperature (b), high $p \mathrm{CO}_{2}(\mathbf{c})$ and high temperature $+p \mathrm{CO}_{2}$ (d) conditions. Aragonite standard peaks occur at 26.2 and $27.2^{\circ}$ (green bars), and the calcite standard peak occurs at $29.4^{\circ}$ (yellow bar).

per sample ( $\sim 36000$ individual spectra were taken per sample). Spectra were similarly taken of both a polished calcite standard and a biogenic aragonite standard to use as references.

\section{Results}

Calcite was not detected in the XRD patterns of any of the skeletons, regardless of treatment. Prominent peaks were observed at $2 \theta \sim 26.2$ and $27.2^{\circ}$, corresponding with the aragonite standard peaks, while no peaks were observed at $2 \theta$ $\sim 29.4^{\circ}$, the location of the primary calcite peak (Fig. 2). After analysing all of the skeletal material using XRD, the more sensitive Raman spectrometry was employed to collect 
spectra from random fragments of the skeleton. Similarly, no trace of calcite was detected in the spectra of any of the treatments. The calcite standard showed peaks at 154, 281, 713 , and $1086 \mathrm{~cm}^{-1}$, and the biogenic aragonite standard showed peaks at $154,205,704$, and $1086 \mathrm{~cm}^{-1}$, which are typical of these polymorphs of $\mathrm{CaCO}_{3}$ (Dandeu et al., 2006). Since both calcite and aragonite peak at $\sim 154, \sim 710$, and $\sim 1086 \mathrm{~cm}^{-1}$, the peaks of interest were the $281 \mathrm{~cm}^{-1}$ peak typical of calcite and the $205 \mathrm{~cm}^{-1}$ peak typical of aragonite (Dandeu et al., 2006). All spectra from all individuals, across all treatments, exhibited peaks typical of only aragonite mineralogy (Fig. 3), with prominent peaks at $\sim 207 \mathrm{~cm}^{-1}$ and no peaks at $\sim 281 \mathrm{~cm}^{-1}$. Both the XRD patterns and Raman spectra collected indicate that neither temperature nor $p \mathrm{CO}_{2}$ had any effect on the skeletal mineralogy of 1-monthold coral recruits, as all skeletons across treatments formed entirely aragonitic skeletons.

\section{Discussion}

Since aragonite is a more soluble polymorph of $\mathrm{CaCO}_{3}$ than calcite, it would be advantageous for modern corals in a rapidly acidifying ocean to be able to produce calcite. Production of calcite has been shown to be a phenotypically plastic, with many marine calcifiers able to adjust both the proportion of calcite in their shell or skeleton as well as the $\mathrm{Mg} / \mathrm{Ca}$ ratio (Ries, 2010, 2011). In this study both temperature and $p \mathrm{CO}_{2}$ were manipulated to assess their impact on skeletal mineralogy of newly settled coral recruits. Neither temperature nor $p \mathrm{CO}_{2}$ affected mineralogy, with all coral recruits analyzed producing entirely aragonitic skeletons. Although temperature has been shown to significantly affect abiotic polymorph precipitation (as a function of $\mathrm{Mg} / \mathrm{Ca}$ ), calcite co-precipitation with aragonite is favoured at cooler temperatures and low $\mathrm{Mg} / \mathrm{Ca}$ ratios $\left(<20^{\circ} \mathrm{C}, \mathrm{Mg} / \mathrm{Ca}<2\right.$, Balthasar and Cusack, 2015). As such, temperature treatments applied in this study $\left(24\right.$ and $\left.27^{\circ} \mathrm{C}\right)$, were within the range of temperatures favouring aragonite production. These temperatures were chosen because they are ecologically relevant to the sub-tropical corals used in this study, under both present ambient and future elevated temperature regimes.

Predicting the impact of high $p \mathrm{CO}_{2}$ on polymorph mineralogy is more complex. The extent to which oscillations between "calcite seas" and "aragonite seas" throughout the Phanerozoic were primarily driven by $p \mathrm{CO}_{2}$ or $\mathrm{Mg} / \mathrm{Ca}$ ratios has received a lot of attention (see review by Ries, 2010). It is accepted that modern adult corals under current ambient conditions produce skeletons comprised entirely of aragonite (Cuif et al., 1999). Furthermore, despite initial work suggesting that new coral recruits were bimineralic (producing both calcite and aragonite), more recent studies have shown that under ambient conditions recruits produce purely aragonitic skeletons (Clode et al., 2011; Higuchi et al., 2014). However, under reduced $\mathrm{Mg} / \mathrm{Ca}$ ratios, both adult and newly

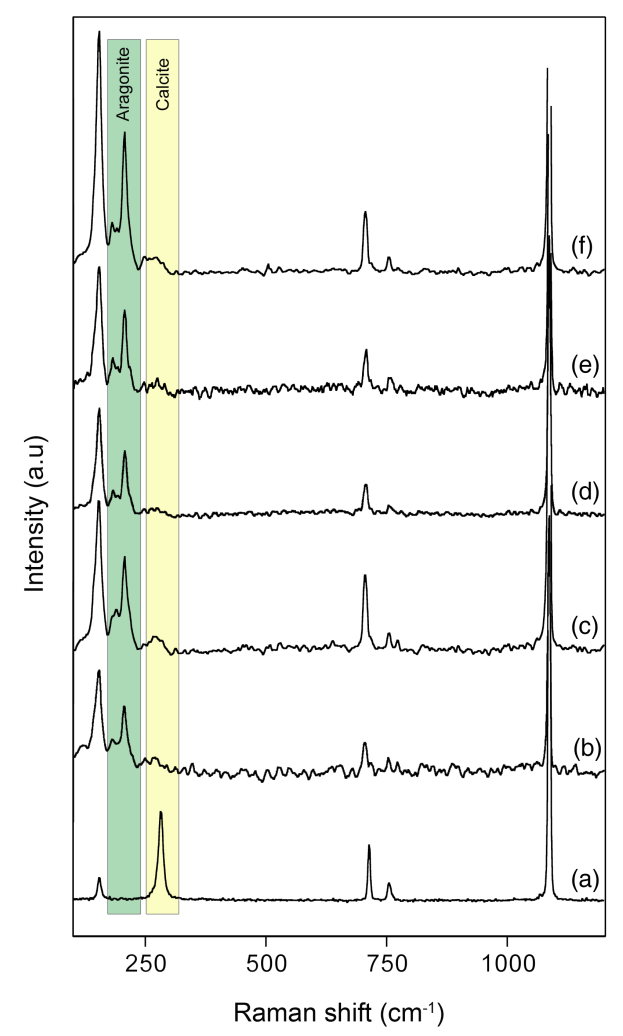

Figure 3. Specific Raman shift of a calcite standard (a) and a biogenic aragonite standard (b) and skeletal material from control (c), high temperature (d), high $p \mathrm{CO}_{2}$ (e), and high temperature $+p \mathrm{CO}_{2}$ (f) treated Acropora spicifera coral recruits. The $\sim 205$ peak specific to aragonite is highlighted in green and the $\sim 281$ peak specific to calcite is highlighted in yellow.

settled corals are able to produce some calcite (Ries et al., 2006; Higuchi et al., 2014). Despite this ability to switch to a bimineralic skeleton, corals still produce skeletons comprised mainly of aragonite, even under extremely reduced $\mathrm{Mg} / \mathrm{Ca}$ ratios (Higuchi et al., 2014), suggesting that the ability of some corals in the fossil record to produce entirely calcitic skeletons (Stolarski et al., 2007) may not have been solely controlled by the $\mathrm{Mg} / \mathrm{Ca}$ ratio of seawater. However, it should also be noted that other coral lineages in the Cretaceous formed entirely aragonitic skeletons, even under highly reduced $\mathrm{Mg} / \mathrm{Ca}$ ratios (Sorauf, 1999). The impact of elevated $p \mathrm{CO}_{2}$ on mineralogy has also been examined for a range of marine calcifiers (Ries, 2011). In bimineralic animals (e.g. whelks), the proportion of calcite in the skeleton increased with increasing $p \mathrm{CO}_{2}$; however in monomineralic animals (entirely aragonitic skeletons), calcite was not incorporated into the skeleton as the $p \mathrm{CO}_{2}$ increased. For the adult temperate coral Oculina arbuscula, a range of $\mathrm{CO}_{2}$ treatments had no impact on skeletal mineralogy, with corals in all treatments producing aragonitic skeletons (Ries et al., 2010). Our study similarly observed no change in skeletal mineralogy under elevated $p \mathrm{CO}_{2}$ for newly settled corals. 
Both the elevated temperature and elevated $p \mathrm{CO}_{2}$ conditions applied in this study were ecologically relevant values, chosen to correspond to future projections for atmospheric $\mathrm{CO}_{2}$ by 2100 , under a business-as-usual (RCP 8.5 ) emissions scenario (Meinshausen et al., 2011; IPCC, 2013). However, applying more extreme values for both temperature and $p \mathrm{CO}_{2}$ could potentially identify changes in the mineralogy under extreme conditions. Nevertheless, this study is part of a growing body of evidence that indicates that corals do not produce calcite under current ambient or predicted nearfuture high $p \mathrm{CO}_{2}$ scenarios, regardless of their life stage. It is likely that new coral recruits will continue to produce aragonitic skeletons under future emissions scenarios, however at reduced calcification rates (Cohen et al., 2009; Anlauf et al., 2011; Foster et al., 2015) and forming skeletons that are smaller, malformed, and show evidence of dissolution (Foster et al., 2016). Recruits require high calcification rates and robust skeletons to both maintain their position on the substrate as they compete with other benthic organisms for space (Dunstan and Johnson, 1998), and also to rapidly outgrow the high mortality rates of the smallest and most vulnerable size classes (Babcock, 1991; Babcock and Mundy, 1996; Doropoulos et al., 2012). Reduced calcification rates and more soluble aragonitic skeletons will have implications for the longer-term survival of young corals, as these factors will increase mortality rates in the early stages of growth and development, thereby reducing the numbers of recruits that survive into adulthood.

While coral recruits exposed to extremely reduced $\mathrm{Mg} / \mathrm{Ca}$ ratios still produced predominantly aragonitic skeletons (Higuchi et al., 2014), the combined impact of elevated $p \mathrm{CO}_{2}$ and reduced $\mathrm{Mg} / \mathrm{Ca}$ ratio on the skeletal mineralogy of new recruits is yet to be tested. Since $p \mathrm{CO}_{2}$ and $\mathrm{Mg} / \mathrm{Ca}$ ratio have varied approximately inversely proportionally to one another over geological time (Reis, 2010, 2011), this would be an interesting direction for future research. Certainly if elevated $p \mathrm{CO}_{2}$ and concomitant reductions in $\mathrm{Mg} / \mathrm{Ca}$ ratio are driving the ocean towards "calcite sea" conditions (Andersson et al., 2008), then it will be important to examine the simultaneous impact of both acidified and low $\mathrm{Mg} / \mathrm{Ca}$ ratio conditions on coral skeletal mineralogy.
Author contributions. T. Foster and P. L. Clode designed the experiment, T. Foster conducted the experiment, T. Foster and P. L. Clode conducted laboratory work, T. Foster wrote the manuscript and P. L. Clode reviewed and commented on the manuscript.

Acknowledgements. This work was funded by the ARC Centre of Excellence for Coral Reef Studies (CE0561435). We thank the Batavia Coast Maritime Institute and the Centre for Microscopy, Characterisation and Analysis (UWA) for access to facilities, T. Becker and A. Dodd for technical assistance with the Raman spectroscopy and X-ray diffraction work respectively and M. McCulloch for project funding and helpful comments on the manuscript. We would also like to thank those who volunteered their time during the experimental phase of this work, particularly; A. Basile, T. Basile, T. Foster, L. Foster, J. Melvin, C. Chua, C. Wood, Z. Snedden, and K. Antipas.

Edited by: A. Shemesh

\section{References}

Andersson, A. J., Mackenzie, F. T., and Bates, N. R.: Life on the margin: implications of ocean acidification on $\mathrm{Mg}$-calcite, high latitude and cold-water marine calcifiers, Mar. Ecol. Prog. Ser., 373, 265-273, 2008.

Anlauf, H., D'Croz, L., and O'Dea, A.: A corrosive concoction: the combined effects of ocean warming and acidification on the early growth of a stony coral are multiplicative, J. Exp. Mar. Bio. Ecol., 397, 13-20, 2011.

Babcock, R. C.: Comparative demography of three species of scleractinian corals using age-and size-dependent classifications, Ecol. Monogr., 61, 225-244, 1991.

Babcock, R. and Mundy, C.: Coral recruitment: consequences of settlement choice for early growth and survivorship in two scleractinians, J. Exp. Mar. Bio. Ecol., 206, 179-201, 1996.

Balthasar, U. and Cusack, M.: Aragonite-calcite seas-Quantifying the gray area, Geology, 43, 99-102, 2015.

Boulos, R. A., Zhang, F., Tjandra, E. S., Martin, A. D., Spagnoli, D., and Raston, C. L.: Spinning up the polymorphs of calcium carbonate, Sci. Rep., 4, 1-6, 2014.

Clode, P. L., Lema, K., Saunders, M., and Weiner, S.: Skeletal mineralogy of newly settling Acropora millepora (Scleractinia) coral recruits, Coral Reefs, 30, 1-8, 2011.

Cohen, A. L., McCorkle, D. C., de Putron, S., Gaetani, G. A., and Rose, K. A.: Morphological and compositional changes in the skeletons of new coral recruits reared in acidified seawater: Insights into the biomineralization response to ocean acidification, Geochem. Geophys. Geosys., 10, 1-12, 2009.

Constantz, B. and Meike, A.: Calcite centers of calcification in Mussa angulosa (Scleractinia), in: Origin, Evolution and Modern Aspects of Biomineralization in Plants and Animals, edited by: Crick, R. E., Plenum Press, New York, 201-207, 1990.

Cuif, J.-P., Dauphin, Y., and Gautret, P.: Compositional diversity of soluble mineralizing matrices in some recent coral skeletons compared to fine-scale growth structures of fibres: discussion of consequences for biomineralization and diagenesis, Int. J. Earth Sci., 88, 582-592, 1999. 
Dandeu, A., Humbert, B., and Carteret, C.: Raman spectroscopy a powerful tool for the quantitative determination of the composition of polymorph mixtures: application to $\mathrm{CaCO}_{3}$ polymorph mixtures, Chem. Eng. Technol., 29, 221-225, 2006.

de Leeuw, N. H. and Parker, S. C.: Surface structure and morphology of calcium carbonate polymorphs calcite, aragonite, and vaterite: an atomistic approach, J. Phys. Chem. B, 102, 2914-2922, 1998.

Doropoulos, C., Ward, S., Marshell, A., Diaz-Pulido, G., and Mumby, P. J.: Interactions among chronic and acute impacts on coral recruits: the importance of size-escape thresholds, Ecology, 93, 2131-2138, 2012.

Dunstan, P. K. and Johnson, C. R.: Spatio-temporal variation in coral recruitment at different scales on Heron Reef, southern Great Barrier Reef, Coral Reefs, 17, 71-81, 1998.

Feely, R. A., Doney, S. C., and Cooley, S. R.: Ocean acidification: present conditions and future changes in a high $\mathrm{CO}_{2}$ world, Oceanography, 22, 36-47, 2009.

Foster, T., Gilmour, J. P., Chua, C. M., Falter, J. L., and McCulloch, M. T.: Effect of ocean warming and acidification on the early life stages of subtropical Acropora spicifera, Coral Reefs, 34, 12171226, 2015a.

Foster, T., Falter, J. L., McCulloch, M. T., and Clode, P. L.: Ocean acidification causes structural deformities in juvenile coral skeletons, Sci. Adv., 2, e1501130, doi:10.1126/sciadv.1501130, 2016.

Goffredo, S., Caroselli, E., Mezzo, F., Laiolo, L., Vergni, P., Pasquini, L., Levy, O., Zaccanti, F., Tribollet, A., Dubinsky, Z., and Falini, G.: The puzzling presence of calcite in skeletons of modern solitary corals from the Mediterranean Sea, Geochim. Cosmochim. Ac., 85, 187-199, 2012.

Higuchi, T., Fujimura, H., Yuyama, I., Harii, S., Agostini, S., and Oomori, T.: Biotic Control of Skeletal Growth by Scleractinian Corals in Aragonite-Calcite Seas, PLoS One, 9, e91021, doi:10.1371/journal.pone.0091021, 2014.

Houck, J. E., Buddemeier, R. W., and Chave, K. E.: Skeletal lowmagnesium calcite in living scleractinian corals, Science, 189, 997-999, 1975.

IPCC, Climate Change 2013: The Physical Science Basis, An overview of the Working Group 1 contribution to the Fifth Assessment Report of the Intergovernmental Panel on Climate Change (IPCC), Cambridge University Press, 2013.

Kontoyannis, C. G. and Vagenas, N. V.: Calcium carbonate phase analysis using XRD and FT-Raman spectroscopy, Analyst, 125, 251-255, 2000 .

Lee, J. and Morse, J. W.: Influences of alkalinity and $p \mathrm{CO}_{2}$ on $\mathrm{CaCO}_{3}$ nucleation from estimated Cretaceous composition seawater representative of "calcite seas", Geology, 38, 115-118, 2010.

Lowenstein, T. K., Timofeeff, M. N., Brennan, S. T., Hardie, L. A., and Demicco, R. V.: Oscillations in Phanerozoic seawater chemistry: evidence from fluid inclusions, Science, 294, 1086-1088, 2001.

Mackenzie, F. T., Bischoff, W. D., and Bishop, F. C.: Magnesian calcites; low-temperature occurrence, solubility and solid-solution behavior, in: Carbonates: Mineralogy and Chemistry, edited by: Reeder, R. J., Mineralogical Society of America, 97-144, 1983.
Meinshausen, M., Smith, S. J., Calvin, K., Daniel, J. S., Kainuma, M. L. T., Lamarque, J.-F., Matsumoto, K., Montzka, S. A., Raper, S. C. B., Riahi, K., Thomson, A., Velders, G. J. M., and van Vuuren, D. P. P.: The RCP greenhouse gas concentrations and their extensions from 1765 to 2300, Climatic Change, 109, 213-241, 2011.

Morse, J. W., Andersson, A. J., and Mackenzie, F. T.: Initial responses of carbonate-rich shelf sediments to rising atmospheric $p \mathrm{CO}_{2}$ and "ocean acidification": role of high $\mathrm{Mg}$-calcites, Geochim. Cosmochim. Ac., 70, 5814-5830, 2006.

Nothdurft, L. and Webb, G.: Earliest diagenesis in scleractinian coral skeletons: implications for palaeoclimate-sensitive geochemical archives, Facies, 55, 161-201, 2009.

Nothdurft, L. D., Webb, G. E., Bostrom, T., and Rintoul, L.: Calcitefilled borings in the most recently deposited skeleton in livecollected Porites (Scleractinia): implications for trace element archives, Geochim. Cosmochim. Ac., 71, 5423-5438, 2007.

Orr, J. C., Fabry, V. J., Aumont, O., Bopp, L., Doney, S. C., Feely, R. A., Gnanadesikan, A., Gruber, N., Ishida, A., Joos, F., Key, R. M., Lindsay, K., Maier-Reimer, E., Matear, R., Monfray, P., Mouchet, A., Najjar, R. G., Plattner, G.-K., Rodgers, K. B., Sabine, C. L., Sarmiento, J. L., Schlitzer, R., Slater, R. D., Totterdell, I. J., Weirig, M.-F., Yamanaka, Y., and Yool, A.: Anthropogenic ocean acidification over the twentyfirst century and its impact on calcifying organisms, Nature, 437, 681-686, 2005.

Ries, J. B.: Review: geological and experimental evidence for secular variation in seawater $\mathrm{Mg} / \mathrm{Ca}$ (calcite-aragonite seas) and its effects on marine biological calcification, Biogeosciences, 7, 2795-2849, doi:10.5194/bg-7-2795-2010, 2010.

Ries, J. B.: Skeletal mineralogy in a high- $\mathrm{CO}_{2}$ world, J. Exp. Mar. Biol. Ecol., 403, 54-64, 2011.

Ries, J. B., Stanley, S. M., and Hardie, L. A.: Scleractinian corals produce calcite, and grow more slowly, in artificial Cretaceous seawater, Geology, 34, 525-528, 2006.

Ries, J. B., Cohen, A. L., and McCorkle, D. C.: A nonlinear calcification response to $\mathrm{CO}_{2}$-induced ocean acidification by the coral Oculina arbuscula, Coral Reefs, 29, 661-674, 2010.

Sandberg, P. A.: An oscillating trend in Phanerozoic non-skeletal carbonate mineralogy, Nature, 305, 19-22, 1983.

Sorauf, J. E.: Skeletal microstructure, geochemistry, and organic remnants in Cretaceous scleractinian corals: Santonian Gosau Beds of Gosau, Austria, J. Paleontol., 73, 1029-1041, 1999.

Stolarski, J., Meibom, A., Przenioslo, R., and Mazur, M.: A Cretaceous scleractinian coral with a calcitic skeleton, Science, 318 , 92-94, 2007.

Vandermeulen, J. H. and Watabe, N.: Studies on reef corals, I. Skeleton formation by newly settled planula larva of Pocillopora damicornis, Mar. Biol., 23, 47-57, 1973.

Wainwright, S. A.: Skeletal organization in the coral, Pocillopora damicornis, Quart. J. Microsc. Sci., 104, 169-183, 1963.

Zhuravlev, A. Y. and Wood, R. A.: Controls on carbonate skeletal mineralogy: global $\mathrm{CO}_{2}$ evolution and mass extinctions, Geology, 37, 1123-1126, 2009. 